\title{
DISTRIBUSI DATABASE PADA ALFAMART \\ DONI WINATA \\ 165100085
}

Fakultas Komputer, 448757197

doniwinata.student@umitra.ac.id

\begin{abstract}
ALFAMART adalah sebuah perusahaan yang bergerak dibidang retail, yaitu menjual barang-barang kebutuhan pokok dan sehari-hari. Kini perusahaan ini telah berkembang dengan pesat seiring dengan berjalannya waktu, dan tentunya sudah mempunyai cabang-cabang yang telah tersebar diseluruh Indonesia dengan nama alfamart.
\end{abstract}

Kata Kunci : DISTRIBUSI DATABASE PADA ALFAMART

\section{A. INTRODUCTION}

DISTRIBUSI DATA BASE PADA ALFAMART

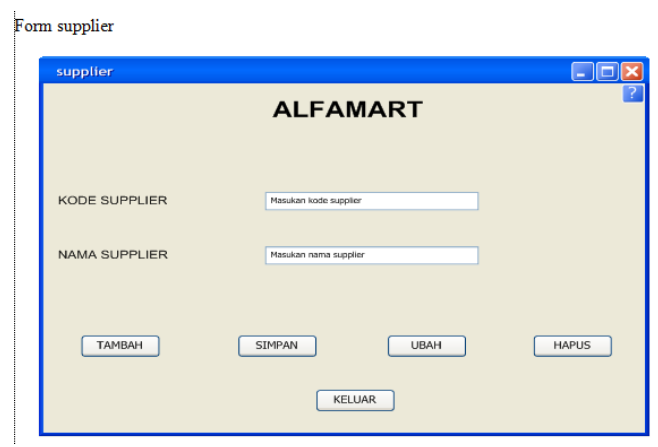

ALFAMART adalah sebuah perusahaan yang bergerak dibidang retail, yaitu menjual barang-barang kebutuhan pokok dan sehari-hari.

Kini perusahaan ini telah berkembang dengan pesat seiring dengan berjalannya waktu, dan tentunya sudah mempunyai cabang-cabang yang telah tersebar diseluruh Indonesia dengan nama alfamart.

\section{Entitas dan atribut yang terlibat:}

1. Entitas SUPPLIER

Atribut :

KD_SUPP

NM_SUPP 
2. Entitas KASIR

Atribut :

NOPEG

PASSWORD

3. Entitas PENJUALAN

Atribut :

NOPEG

KD_BRG

NO_KWI

JML_BRG

JENIS_TRX

TTL_BYR

4. Entitas BARANG

Atribut :

KD_BRG

NM_BRG

HARGA

JENIS

MERK

STOK

\section{Deskripsi Data}

1) ENTITAS SUPPLIER

KD_SUPP (kode supplier)

NM_SUPP (nama supplier)

2) ENTITAS KASIR

NOPEG ( Nomor Pegawai)

PASSWORD (Password Pegawai)
3) ENTITAS PENJUALAN

NOPEG (Nomor Pegawai)

KD_BRG (Kode Barang)

NO_KWI (Nomor Kwitansi)

JENIS_TRX (Jenis Transaksi)

JML_BRG (Jumlah barang yang

dibeli per kode barang)

TTL_BYR (Jumlah uang yang dibayar)

4) ENTITAS BARANG

KD_BRG (kode barang)

NM_BRG (nama barang)

HARGA (harga barang)

JENIS (jenis barang)

MERK (nama merk barang)

STOK (stok barang)\}

\section{ERD (entity relationship diagram)}

Arsitektur basis data

Konsep pemrogramman three tier

(3 tier) atau yang biasa disebut dengan konsep client server programming merupakan konsep pemrograman yang terdiri dari 3 komponen logic layer yang saling berkaitan. Berikut gambaran secara umum untuk arsitektur pemrogramman model three-tier 
memiliki 3 fungsionalitas sistem yang independent, yaitu :

a) Komponen klien (Client application) yaitu komponen yang berjalan diatas local komputer user / client. (tier 1) Pada layer ini, akses tidak bisa sampai pada RDBMS layer jika tidak ada koneksi ke aplikasi server (layer 2 / tier 2).

b) Aplikasi server (Aplication server) yaitu komponen yang berjalan pada remote server yang berfungsi sebagai koneksi antara klien dengan database system. (Tier 2). Pada layer ini, merupakan layer yang menghubungkan antara layer client (tier 1) dengan layer RDBMS Application (tier 3). layer ini berisi package, objek, method, fungsi dan segala aktifitas query yang akan dijalankan pada layer 3 / tier 3 (RDBMS Application).

c) Aplikasi RDBMS (RDBMS Application) yaitu kumpulan database, data resource manager dan aplikasi mainframe (Tier 3). Pada layer ini, berisi kumpulan database dan data resource manager yang merupakan pusat database suatu sistem. Layer 3 / tier 3 atau aplikasi RDBMS, tidak bisa diakses secara langsung melalui layer 1 / tier 1 atau aplikasi klien. jika aplikasi klien tidak terkoneksi ke layer 2 / tier 2 atau aplikasi server .

Layanan presentasi atau logika antarmuka pengguna ditempatkan pada mesin client. Logika bisnis dikeluarkan dari kode client dan ditempatkan dalam tingkat menengah. Lapisan layanan data berisi server database. Setiap tingkatan dalam model three-tier berada pada komputer tersendiri. Konsep model three-tier adalah model yang membagi fungsionalitas ke dalam lapisanlapisan, aplikasiaplikasi mendapatkan skalabilitas, keterbaharuan, dan keamanan.

Arsitektur Three Tier merupakan inovasi dari arsitektur Client Server. Pada arsitektur Three Tier ini terdapat Application Server yang berdiri di antara Client dan Database Server. 
Contoh dari Application server adalah

IIS, WebSphere, dan sebagainya. Application Server umumnya berupa business process layer, dimana bisa didevelop menggunakan PHP, ASP.Net, maupun Java. Sehingga kita menempatkan beberapa business logic kita pada tier tersebut. Arsitektur Three Tier ini banyak sekali diimplementasikan dengan menggunakan Web Application. Karena dengan menggunakan Web Application, Client Side (Komputer Client) hanya akan melakukan instalasi Web Browser.

Dan saat komputer client melakukan inputan data, maka data tersebut dikirimkan ke Application Server dan diolah berdasarkan business processnya. Selanjutnya Application Server akan melakukan komunikasi dengan database server. Biasanya, implementasi arsitektur Three Tier terkendala dengan network bandwidth. Karena aplikasinya berbasiskan web, maka Application Server selalu mengirimkan Web Application-nya ke komputer Client. Jika kita memiliki banyak sekali client, maka bandwidth yang harus disiapkan akan cukup besar, Sedangkan network bandwidth biasanya memiliki limitasi. Oleh karena itu biasanya, untuk mengatasi masalah ini, Application Server ditempatkan pada sisi client dan hanya mengirimkan data ke dalam database server. Konsep model threetier adalah model yang membagi fungsionalitas ke dalam lapisanlapisan, aplikasiaplikasi mendapatkan skalabilitas, keterbaharuan, dan keamanan.

\section{B. CONCLUSION}

ALFAMART adalah sebuah perusahaan yang bergerak dibidang retail, yaitu menjual barang-barang kebutuhan pokok dan sehari-hari.

Kini perusahaan ini telah berkembang dengan pesat seiring dengan berjalannya waktu, dan tentunya sudah mempunyai cabang-cabang yang telah tersebar diseluruh Indonesia dengan nama Alfamart. 
Kelebihan sistem yang dibangun yaitu membantu proses penjualan dan pembelian barang dengan menerapkan system administrasi yang kuat untuk Pencatatan dari barang masuk, penyimpanan barang di gudang, sampai dengan barang keluar atau dijual.

Kekurangan sistem yang dibuat ruang lingkup yang terbatas sehingga hanya membahas barang atau suatu produk berupa fisik.

Perlu dikembangkannya sistem yang dibangun dengan ruang lingkup yang luas seperti terintegrasinya dengan penjualan tiket pesawat, atau pembayaran yang lainnya.

Beberapa Kelebihan Arsitektur ThreeTier :

1) Keluwesan teknologi.

2) Mudah untuk mengubah DBMS engine.

3) Kemungkinkan pula middle tier ke platform yang berbeda.

4) Biaya jangka panjang yang rendah.

5) Perubahan-perubahan cukup dilakukan pada middle tier daripada pada aplikasi keseluruhan.

6) Keunggulan kompetitif.

7) Kemampuan untuk bereaksi terhadap perubahan bisnis dengan cepat, dengan cara mengubah modul kode daripada mengubah keseluruhan aplikasi.

Kekurangan arsitekture Three Tier :

1) Lebih susah untuk merancang.

2) Lebih susah untuk mengatur.

3) lebih mahal.

\section{ACKNOWLEDGEMENT}

University Of Mitra Indonesia 
D. REFERENCE (Based ISO 690 )

[1]

A. S. Putra And O. M. Febriani, "Knowledge Management Online Application In Pdam Lampung Province," In Prosiding International Conference On Information Technology And Business (Icitb), 2018, Pp. 181-187.

[2] A. S. Putra, O. M. Febriani, And B. Bachry, "Implementasi Genetic Fuzzy System Untuk Mengidentifikasi Hasil Curian Kendaraan Bermotor Di Polda Lampung," J. Sist. Inf. Dan Manaj. Basis Data, Vol. 1, No. 1, Pp. 21-30, 2018.

[3] O. M. Febriani And A. S. Putra, "Sistem Informasi Monitoring Inventori Barang Pada Balai Riset Standardisasi Industri Bandar Lampung," J. Inform., Vol. 13, No. 1, Pp. 90-98, 2014.

[4] Putra, Arie Setya. "2018 Artikel Struktur Data, Audit Dan Jaringan Komputer." (2018).

[5] Putra, A. S. (2018, July 17). Paperplain Fundamental Create Application With Borland Delphi 7.0 University Of Mitra Indonesia. Retrieved From Osf.Io/Pbrn9.

\section{E. REFERENCE (Based APA)}

Putra, A. S., Aryanti, D. R., \& Hartati, I. (2018, November). Metode SAW (Simple Additive Weighting) sebagai Sistem Pendukung Keputusan Guru Berprestasi (Studi Kasus: SMK Global Surya). In Prosiding Seminar Nasional Darmajaya (Vol. 1, No. 1, pp. 85-97).

Sari, D. P., Febriani, O. M., \& Putra, A. S. (2018, November). Perancangan Sistem Informasi SDM Berprestasi pada SD Global Surya. In Prosiding Seminar Nasional Darmajaya (Vol. 1, No. 1, pp. 289-294).

Putra, A. S. (2018). Paperplain: Execution Fundamental Create Application With Borland Delphi 7.0 University Of Mitra Indonesia.

Putra, A. S., Sukri, H., \& Zuhri, K. Sistem Monitoring Realtime Jaringan Irigasi Desa (JIDES) Dengan Konsep Jaringan Sensor Nirkabel. IJEIS (Indonesian Journal of Electronics and Instrumentation Systems), 8(2), 221232.

Darmawan, A., Yuliawati, D., Marcella, O., \& Firmandala, R. (2016). Sistem Absensi dan Pelaporan Berbasis Fingerprint dan SMS Gateway. EXPLORE, 7(1).

Febriani, O. M., Wahyuni, T., \& Yusuf, S. (2017). DESIGN OF WEBSITE-BASED INFORMATION SYSTEM FOR EDOCUMENT ADMINISTRASI IN THE COMMUNITY SERVICE UNIT (A Case Study at Rajabasa District). INTERNATIONAL JOURNAL OF 
COMPUTERS \& TECHNOLOGY, 16(7), 7010-7020.

Febriani, O. M., \& Wahyuni, T. (2017, October). PERANCANGAN SISTEM E-DOCUMENT ADMINISTRASI LOGBOOK PENELITIAN PADA UNIT LAYANAN DI BANDAR LAMPUNG. In Prosiding Seminar Nasional Darmajaya (Vol. 1, No. 1, pp. 187-194).

Febriani, O. M., \& Permadi, A. B. (2017). Implementasi Sistem Aplikasi Data Bimbingan dan Pelanggaran Siswa pada Sekolah Menengah Atas di Lampung Tengah dengan Metode Analisis dan Desain Sistem Terdistribusi (SSAD). EXPERT, 7(1).

Febriani, O. M., \& Ambarwati, L. (2015). PERANCANGAN APLIKASI PENGOLAHAN DATA PENJUALAN UKM KELANTING KHAS TELO DESA SIDOHARJO KECAMATAN JATI AGUNG KABUPATEN LAMPUNG SELATAN. Jurnal Teknologi Informasi dan Bisnis Pengabdian Masyarakat Darmajaya, 1(1), 77-95.

Febriani, O. M. (2015). Rancang Bangun Aplikasi Ecommercemenggunakan Freewebstore pada UKM Kelanting di Desa Sidoharjo Lampung Selatan. Prosiding Sembistek 2014, 1(02), 446-458. 